\title{
NYUNGARS AND WORK: ABORIGINAL EXPERIENCES IN THE RURAL ECONOMY OF THE GREAT SOUTHERN REGION OF WESTERN AUSTRALIA
}

\author{
Sally Hodson
}

\section{Introduction}

From the turn of the century until the 1960 s, when they became marginalised as workers as a result of structural and technological changes in the rural economy, Nyungars ${ }^{1}$ in the Great Southern Region of Western Australia (Map) were a convenient pool of reserve labour for wheat and sheep farmers as seasonal and economic conditions required. Usually they were engaged in contract work - shearing, crutching, ${ }^{2}$ clearing and fencing - and domestic work. Not only was the participation of Nyungars in the capitalist economy necessary for their survival, since much of the land on which they had formerly hunted and gathered had been cleared with the development of the wheat belt, but they were also subjected to intense pressure from government administration to adopt European work values and behaviour. Yet, as an increasing number of anthropologists have come to realise in recent years, local populations are not merely reactive in the face of these external forces operating upon them.

In this paper, I examine the nature of the Nyungar interaction with the capitalist economy by drawing on the oral testimonies of Aboriginal and non-Aboriginal people 3 relating to the period from the mid 1930s to 1970 . Components of this interaction are kinship ties and work; patterns of work; value of bush resources; Nyungar and capitalist value systems; and relationships between Nyungars and farmers. Finally, Nyungars' skills in managing adaptation to change are reflected in their assessments of the value of their contribution to the regional rural economy.

\section{Kinship and work}

The aim of the Western Australian administration (the Department of Native Affairs and its successor the Department of Native Welfare) was to control and train Nyungars in an effort to make them more acceptable to the European community. The inculcation of the European work ethic was seen as an integral part of this training which, for younger Nyungars at least, meant preparation for individual success in the wider society, albeit at its lower levels. However, as will be shown in the following section, the social imperative

Sally Hodson completed her MA degree in Anthropology at the University of Western Australia in 1989 and since then has been working in North and Central Australia.

1 The word Nyungar (alternatively spelt Nyoongah, Noongar, Nungar, Noongiah, Njungah, meaning 'man' or 'person', is the generic name which the Aboriginal people living in the south-western corner of Western Australia, south and west of a diagonal line extending from just south of Geraldton to just west of Esperance (see map), use to refer to themselves.

2 Crutching refers to the process of removing wool from the hindquarters of sheep to prevent them from becoming fly-blown.

3 I spoke with twenty-five Nyungar people, fifteen men and ten women aged between 45 and 80 . I also interviewed eight non-Aboriginal famers; a former Protector; a retired teacher, a missionary couple; and a former District Officer with the Department of Native Welfare. Material drawn from taped interviews is referenced by the letter ' ' followed by the tape number. Material drawn from untaped interviews is referenced by the letter ' $\mathrm{T}$ ' followed by the number assigned to that interviewee. These interviews, carried out in 1986 and 1987, were part of the research for an MA. 


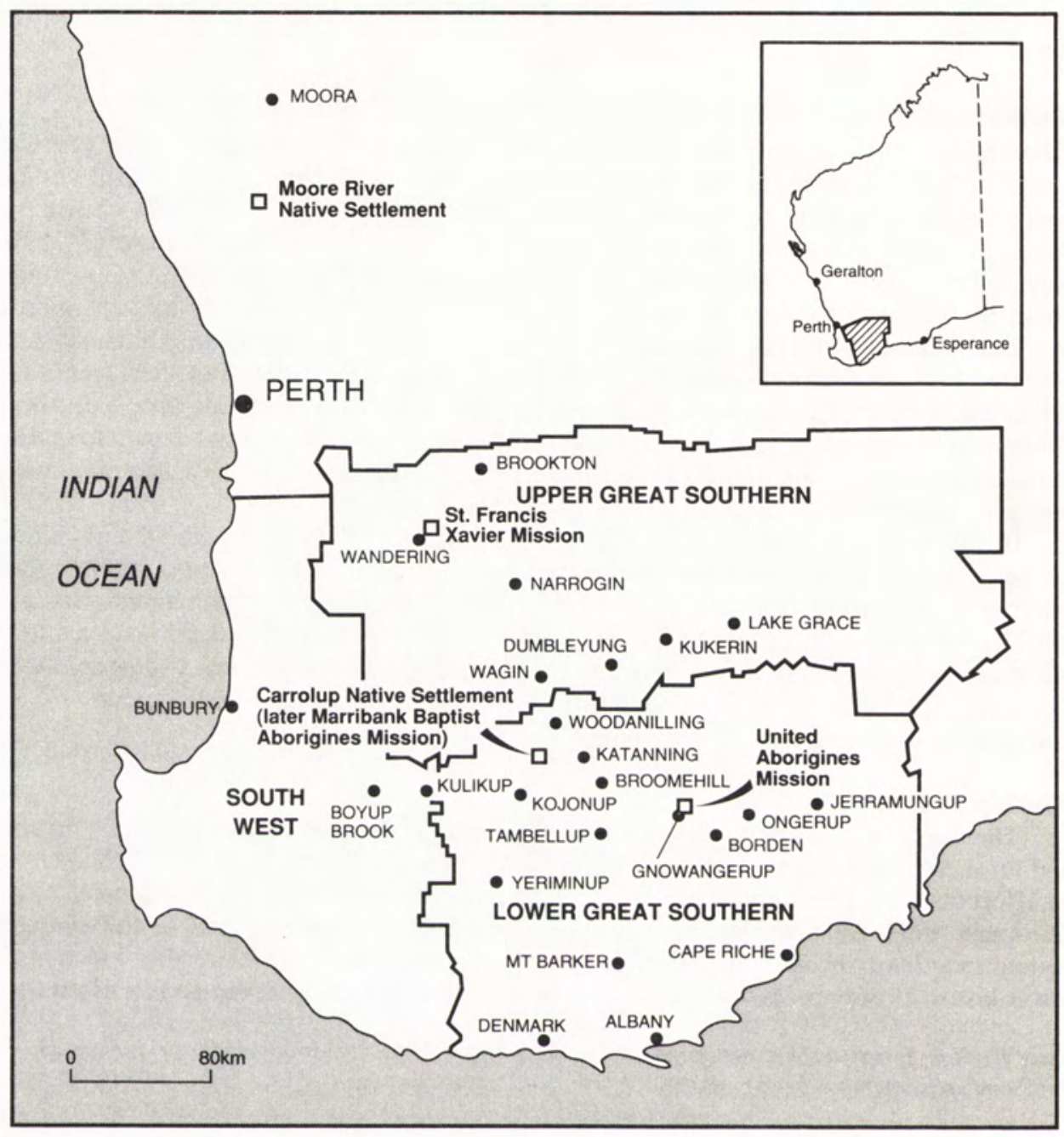

The Great Southern Region, Western Australia 


\section{NYUNGARS AND WORK IN SOUTHERN WESTERN AUSTRALIA}

remained strong for Nyungars, with kinship ties influencing where people worked, with whom they worked, the type of work that they did and how they shared the available resources.

The basic Nyungar economic unit was the household, defined as those who occupied the same house or camp. While this typically consisted of parents and their children, the domestic boundary was very flexible and members would frequently be joined by other close relatives: unmarried uncles and aunts, widowed grandparents, nephews and nieces. Birdsall ${ }^{4}$ comments on the Nyungar practice of sending children to live with their mother's kin for varying periods of time throughout their childhood; while the oral histories indicate that young men in particular often spent time with different uncles and aunts before they married. Moreover, in some families the father might be absent from the household, either temporarily because of work or imprisonment, or permanently through marital separation or death. In these situations the woman left on her own with children would often join her parents' household. Thus, the actual composition of the basic Nyungar economic unit varied greatly.

The work performed by Nyungar men and women in the paid economy was made possible by the division of labour within the household whereby women assumed responsibility for the unpaid domestic tasks: cooking, washing and childcare. Nyungar women also contributed to the family finances, and some were the sole providers either because they were single, separated or widowed, or because their husbands, as a result of illness, age or injury, were no longer able to work. The records and annual reports of the Department of Native Affairs up to the 1950s depict women as involved only in domestic employment. This, however, is more a reflection of the assumptions held by administrators regarding the most suitable work for women than of the real situation. A different picture emerges from the Aboriginal narratives, one which shows that many women worked with the men on clearing contracts. The contribution of women was freely acknowledged by the male interviewees: 'she worked like a man' was a description frequently applied to wives or female relatives. While shearing did not entail the same involvement of women, there were those who worked regularly as shed hands and a few also did stock work.

When the type of work and the demands of schooling ${ }^{5}$ permitted it, children worked alongside their parents, and in this way farming skills were transmitted from one generation to the next. The process began informally from quite an early age as children played in the paddocks near the adults. As they grew older they helped by picking up stones and small roots, pouring poison around tree stumps and looking after the smaller children. Cutting posts and fencing was another area where children could assist by gathering the posts into heaps and helping to 'run out' the fencing wire. An informant remembered, too, that when he and his wife took on large mallee clearing contracts, their children drove the tractor while they followed behind loading the trailer with roots ( $T$ 7). Later on, Nyungar boys worked as shed hands in the family team and were given the chance to gradually acquire shearing skills. While girls learned about some aspects of agricultural work along with the boys, they also learned about domestic work from their mothers and other close female relatives. However, the living circumstances of many Nyungars, particularly up until the 1960 s when most people still camped on farms and on reserves on the outskirts of country towns, did not lend themselves to the transmission of all the domestic skills required by

\footnotetext{
$4 \quad$ Birdsall 1988, p. 143.

5 Education became compulsory for Aboriginal children in 1948 .
} 


\section{ABORIGINAL HISTORY $1993 \quad 17: 1$}

European employers. Therefore, it was usually those girls who spent time in missions and settlements ${ }^{6}$ who acquired these particular skills.

Kinship was the key principle in the Nyungar organisation of contract work. Although the size of the work unit was fluid, depending on the availability of work and the size of the job to be done, those working together were invariably close relatives. Clearing, in particular, was seen as 'a family thing' as the nature of the work permitted, and in many cases required, a team approach. A sequence of tasks was spread out over a number of years. First, the heavier timber was chopped down and the tree stumps ringbarked and poisoned. Where timber was smaller, tractors were often used to roll down the vegetation. The following year towards the end of summer the burning up of vegetation and trees took place, sometimes with the use of horses to drag the larger logs into piles. The newly cleared land was then ploughed, but before seeding could take place the stumps and mallee roots had to be collected and burnt, and stones piled into heaps. This process was repeated each year until ploughing no longer turned up roots and stones.

While some households liked to operate on their own when they cleared land, people generally preferred to work with wider networks of kin. When a large contract was taken on, the acreage was either divided up into smaller areas which were allocated to individual households, or everyone worked together on the same job. Most commonly, close male relatives and their families worked together - for example, parents with their adult sons and daughters-in-law or brothers and their wives. It was also not unusual for a man to work with his wife's relatives, with her father, brothers or uncles ${ }^{7}$ and their families. Some work teams encompassed three generations. The size of the work units varied, with individual households 'meeting up' for some jobs and then going off to do others on their own, yet the combinations that together formed the larger groups tended to remain fairly stable. One man, for example, remembers that his family almost always worked with his mother's sister and her husband and children ( $T$ 19). Young men moved around a lot, working and spending time with different members of their extended families, particularly their maternal or paternal uncles, before they married and established regular work relationships.

Clearing contracts were negotiated between the person who took on the job and the farmer, and it was this person who was paid on completion of the contract. The money was then shared out among all the members of the team after the deduction of any expenses incurred by the contractor: for example, for tobacco, equipment such as axes, files, oilstones and water bags and, in some cases, 'the odd booze up'. The usual practice was that the proceeds of these collective endeavours were divided among participants according to their contributions, although several 'key men' in the Great Southern Region employed their own work teams and ran profitable enterprises allowing material accumulation.

Shearing was the other main task carried out by Nyungars. It formed the backbone of their work year, with clearing being fitted in around shearing. The season lasted for two to three months from August or September, and even those men who were not shearers were usually involved as shed hands or wool pressers. Six months later the shearers returned to

6 In the Great Southern Region during the period under consideration these consisted of the Carrolup Native Settlement, which reopened in 1940 and operated until 1952 when it was handed over to the Baptists Aborigines Mission; Gnowangerup Mission which closed in 1985; and the St Francis Xavier Mission at Wandering which opened in 1950.

7 Nyungars move in a world which is typically full of kin and the kinship idiom is used very generally as the following quote indicates:

1 still call people uncle and aunt who are my second cousins but that's the way things happen in this area, there's no such thing as a second cousin, even your mother's cousin or your father's cousin was your uncle or aunt ... My first cousins are like my brother or sister and it wasn't uncommon for aunties to rear up nephews and nieces and they call her 'Mum" or call their natural mother 'Mum' and call their aunt 'Mum' too. That happened a lot (T 7). 


\section{NYUNGARS AND WORK IN SOUTHERN WESTERN AUSTRALIA}

their regular sheds to do the crutching, a much faster job involving only a few days at each shed, and to shear the lambs that had been too small at shearing time.

Shearing teams were also made up of relatives and once again the size of the job largely determined the size of the work unit, as a Nyungar man explained:

Sometimes the shed was big enough for all of them to work in and at other

times the sheds weren't and of course they would go to other smaller sheds, they would split up (T 4).

As with clearing contracts, one person would act as representative for the team, making the necessary arrangements with the farmer and sorting out any problems that arose. Each member of the team, however, was paid separately according to the number of sheep he had shorn or, in the case of shed hands, at a daily rate.

Other forms of employment were not as amenable to the operation of the kinship principle as contract work. The unskilled labouring jobs which became available to Nyungars from the 1950 s were usually positions for individuals rather than groups. Nevertheless, the kinship network continued to operate to a certain extent as an avenue for finding employment. Thus, by recommending relatives or letting them know when jobs were available, Nyungars could sometimes arrange that they were working with kin. This was often the case with the various public works programs which generally employed Aborigines in groups, rather than singly, as did the abattoirs and the woollen and timber mills.

With paid domestic work women seldom had the opportunity to work with other Nyungars, and this sense of isolation, particularly in live-in situations, undoubtedly contributed to the reported reluctance of young Nyungar women to take up this employment. ${ }^{8}$ Glenyse Ward ${ }^{9}$ gives a graphic description of the loneliness experienced by live-in domestics in her autobiography, Wandering Girl, which she dedicates to '... all the Aboriginal women who, as girls, had to face hard times working on white people's farms in the Great Southern and other districts of their own country'. Live-in positions were taken mainly by young single women sent out from the missions and settlements. More commonly, Nyungar women living in or near towns would work for a number of employers - the wives of doctors, local businessmen and farmers - on a regular basis. They would wash, clean, iron, polish the silver, clean windows, scrub floors; in short, 'do all the work the white women didn't want to do' (T 25). More rarely, they looked after children.

Nyungar women who lived on farms with their families sometimes worked in the farmhouses, but many were fully occupied caring for their own families or preferred to be out in the paddocks with their husbands. It seems that this preference was based not only on the desire to work with other Nyungars, but also on a dislike of being in the position of servant and of being closely supervised. Haebich ${ }^{10}$ also documents this preference for agricultural work among many Nyungar women who, as she puts it, disliked working 'under the eagle eye of white mistresses'. A woman interviewee remembered that her mother refused to work in other people's houses because 'she was a very proud woman, she wasn't going to be a lackey for anybody'. Instead, she helped support her family by milking cows twice a day at the local convent for sixteen years without a break (T 25). The archival material indicates that a reluctance to leave home and to be in an environment where there were no other Nyungars also deterred a number of young women from taking on other kinds of work.

AR 1951, p. 14; AR 1963, p. 39.

Ward 1987.

10 Haebich 1985, p.250 
An important aspect of Nyungar social relations was the obligation to share resources with close kin. This was stressed by many of the Nyungar interviewees, and the European administrators and farmers also frequently commented on the Nyungar 'communal spirit'. People shared contract work when it was available; as one man explained, if you saw somebody who had no work, you'd say "well, you can come and have a hundred acres" or something like that' (T 19). Food, shelter and money were other resources shared by Nyungars. The following extracts from the Nyungar narratives express the high value that was placed on this ideal:

Nyungars, they will always be very good natured towards one another. If so and so didn't have any bread or meat or sugar, if he went to the next person and they had some, they'd share and share alike, with food ( $T$ 15).

... we'd share everything. If one Nyungar had a five pound note, he'd give the other bloke half, that's how we were. Nobody was broke if his mate had money, this is why Nyungars are still broke today (T 10).

The practice of sharing was essential to Nyungar survival. The Department of Native Welfare was clearly aware of this fact although it opposed the practice because it was seen to militate against individual success. During the 1950s, when the demand for Nyungar labour had declined and Aborigines had only restricted access to Social Service benefits, the Southern District Officer commented that the communal spirit was particularly evident during times of unemployment and that 'even obtaining subsistence would be difficult if they did not assist each other from time to time.. ${ }^{11}$ It was not only the unemployed but also widows, invalids and old people who were supported by their kin. After pensions were made generally available to Aborigines in 1960 (except for those considered to be 'nomadic' or 'primitive'), the Superintendent of the Southern Division noted that there had been a marked economic improvement amongst pensioners. These people had previously comprised what he referred to as 'the "hanger-on" section of the native population' because they had 'lived off the charity of relatives'. ${ }^{12}$

Each of the extended kinship networks or clusters of interrelated families ${ }^{13}$ to which most Nyungars belong was, and continues to be, associated with a particular stretch of country known as a 'run', which was identified by the string of places within it. For example, 'my family's run stretched from Kukerin, Dumbleyung, Katanning, Broomehill, around Kojonup, Kulikup and the Boyup Brook area' (T 3). These places were also recognised by other Nyungars as 'belonging' to that family group. Others writing about Nyungars have also noted the existence of 'runs'. ${ }^{14}$ Haebich ${ }^{15}$ found that Nyungars often had ties of traditional ownership with their runs, and my own research also suggests that this was the case. The Nyungar interviewees indicated strong attachments to these areas even if they had moved to the city many years before - and a desire to be buried there alongside their relatives.

The loosely drawn boundaries of the family run defined the area within which Nyungars moved in search of work. As one man explained,

See, it was in Ongerup where the Woods, they had that area around Ongerup, they'd do all the shearing and the picking and the haycarting, and then Borden, there was Harry Brown and the Roberts and then in Gnowangerup

11

12

13

14

15

NA 94/1954; AR 1957, p. 10.

AR 1963, p. 18.

Birdsall 1988 adopts the term 'all one family' to refer to such a group. She observes that each group has a sumame which is used when people are discussing the kin group affiliation of individuals.

For example, Birdsall 1988, p. 141; Haebich 1988, p. 36; Toussaint 1987, pp. 81-2.

Haebich 1988, p. 36. 


\section{NYUNGARS AND WORK IN SOUTHERN WESTERN AUSTRALIA}

there was the Williams and there was some Woods too and Picketts. Some of the names I've missed out ... the Pennys, there was a lot of Pennys in Borden (T 15).

Since Nyungars tend to establish close relationships among an extended network of kin through both their mother and father, there was the option, when parents came from different areas, of moving to another run. This practice seems to have been quite common among young men before they married.

Within each run there were particular places where people met up between jobs and these often had traditional or historical associations. One such place was Cape Riche on the south coast between Albany and Esperance, which had once been a camp site used by Nyungars employed by pastoralists as shepherds along this stretch of coast. Another meeting place was at Woodanilling where a woman remembers her family camping,

... on a piece of crown land with access to water and far enough from the townsfolk that they weren't screaming their heads off. Other Nyungars camped there all the time, that's where they used to meet, play games, tell their stories (T 25).

The designated reserves on the outskirts of some of the towns also served as meeting places and somewhere to live between jobs.

People often moved in a circular fashion around their run, particularly during the shearing and crutching seasons. It is in this context that a second use of the term 'run' - to refer to a particular string of sheds at which people 'shore' each year - can be distinguished, a use which was not limited to Aborigines but was common throughout the pastoral industry. ${ }^{16}$ The following quote from one of the Aboriginal narratives illustrates this use of the term:

The Nyungars had a run they used to do every year, they used to go from one shed to another and one lot would do ... Tambellup way and we'd go out around Borden and there was another mob out around Ongerup way (T 17).

Although men often worked the same shearing runs as their fathers, it was also not uncommon for them to establish separate runs.

In concluding this discussion of kinship and work it can be said that kinship pervaded Nyungar social and economic life. In his analysis of the nature of contact between capitalist and non-capitalist societies, Wolf ${ }^{17}$ maintains that in order to transform people into economic actors they have to be made independent of prior social commitments to kin. In spite of the administration's attempts to effect such a transformation, Nyungar collective activities and values persisted.

\section{Work patterns}

Most Nyungar people worked under contract. Certainly, very few waged positions were available to them at this time, but even so, almost every interviewee stated a definite preference for contract work, a preference which was explained in the following ways:

I was a wage earner at times, wages were OK but they wasn't as good as contract. It was something we did if there was nothing else available, it was the money I was chasing (T 8).

If you go out and do a day's work, you sort of take your time doing it, well, I'm only talking about root picking anyway. But if it was done on a

16 The term 'run' has commonly been used in the pastoral industry in two ways: to refer to land occupied by 17 pastoralists and to refer to the seasonal migratory pattem of casual workers

7 Wolf 1971 , p. 279. 


\section{ABORIGINAL HISTORY $1993 \quad 17: 1$}

contract basis you got stuck into it, try and get the job done quick as you can. The quicker you got it done, the more money you earned (T 15).

You'd work better for yourself, see, you could please yourself when you worked. When you worked with the farmer you'd be sitting down at dinner, then you'd have to go right out again carting hay again, but when you got the contract work you could say 'right', before the sun rises you can go out and work, see, when it's nice and cool. Once it gets a bit warmer, you can lay off until about 3 or 4 o'clock and then start working until 7 . Sometimes when I was burning up I'd go till 12 o'clock at night (T 32).

These narratives contain two rationales for this preference for contract work. The first, that it was more lucrative, and the second, that it allowed workers more autonomy in terms of when, how and with whom they worked. It is likely that a desire for mobility was also involved. As one woman observed, 'Nyungars never stop still, you know' (T 21). In relation to the first point, it is interesting to note that the archival evidence indicates that it was not uncommon for people to leave regular jobs and go shearing, although, in the long run, they were usually financially disadvantaged by the move. ${ }^{18}$ This suggests that there was more than money involved when people decided to give up secure positions for lucrative, but brief, seasonal employment. The second rationale, that relating to autonomy in the work place, is an important one that needs to be examined more closely.

In a well known article, Thompson ${ }^{19}$ draws attention to the distinction between taskoriented labour which exists in pre-industrial societies and time-measured labour which predominates under capitalism. This distinction has been used in the Australian context by Morris ${ }^{20}$ when comparing the pre-contact and current work practices of Aboriginal people in northern New South Wales. It is also useful in discussing the work experience of Nyungars. Thompson ${ }^{21}$ notes that task-oriented labour is characterised by irregular work patterns where bouts of intense labour alternate with periods of idleness, and he asks whether this is not in fact a 'natural' work rhythm. Certainly, when Nyungars were employed under contract, they tended to work without regard to clock time and to vary their work pace. Tonkinson, ${ }^{22}$ commenting on the 'lack of appreciation of time' in his study of Aboriginal people in the Narrogin area, says that he never saw a Nyungar wearing a wristwatch and that there was also a lack of clocks. Nyungars are aware of the European preoccupation with the clock as a measure of human labour time, in fact of all human activities, and often refer jokingly to 'Nyungar time', by which they mean an indifference to the clock and a corresponding lack of punctuality. When the task demanded it they were prepared to work long hours. During the burning off phase of clearing, for example, people often had to wait until the evening for the breeze which was needed to fan the flames. As a consequence:

You would work most of the night burning off what you had stacked during the day and you could have a hundred acres on fire ... Thousands of fires and all those fires had to be stoked, all the ends when it burnt down, chuck them all together again and they would burn out ... 12, 16 hours, up to 20 hours a day, this was a normal day if you was contract root picking because you would start as early as you possibly could in the morning and you'd work all night if you wanted to, if you had to (T 8).

\footnotetext{
NW $115 / 1956$.

Thompson 1967.

Morris 1983.

Thompson 1967, p. 73.

Tonkinson 1962, p. 114.
} 


\section{NYUNGARS AND WORK IN SOUTHERN WESTERN AUSTRALIA}

At other times, however, they worked at a slower pace and took time off to join up with relations at one of the regular meeting places in the Great Southern Region. Spending time with kin, as indicated in an earlier section, was very important to Nyungars and contract work allowed them more opportunities to 'meet up' than did regular wage employment, since they could suit themselves to a certain extent about when and for how long they worked.

Contract work also permitted the integration of 'life' and 'work' which, I would suggest, was how Nyungars themselves preferred to operate. One farmer recalled that when he contracted someone to do a clearing job, 'half a dozen might turn up and do it and they'd all knock off and kick a football around or something' ( $\mathrm{T}$ 34); and another observed that Nyungars 'are inclined to treat it [ie. work] as a way of life rather than making a lot of money' (T 27). With contract work, children became familiar with the world of work from an early age, often treating it as a game. One woman remembers helping her father as a child:

There was a lot of stones dug up out of the ground. I said 'We'll build a house out of the stones', it was more like fun you know. Kids used to run around building these big castles of stone [laughs] (T 21 ).

Spatially, too, there was often little separation between their place of work and where they lived, since Nyungars usually camped in the paddocks close to where they were clearing. Washing, rather than being a solitary and onerous chore, tended to be a sociable activity. One man recalls that on the reserve,

Washing was a woman's job. They'd make a day of it, go to the nearest dam and get into it, stay there all day ... a group of women laughing away and having a good time there doing the washing ( $T$ 9).

The absence of the clearly defined boundaries between 'work' and 'life' which exist in capitalist societies is even more obvious when we look at subsistence activities. People recall with pleasure collecting 'bush tucker' and catching rabbits for sale and domestic consumption:

We got them out of the root heaps or used a gun or a stick, we used to go and

knock them on the head with that, but that was more or less a sport we used to have on a Sunday ... A great mob of us used to go down to the river and chase these rabbits around ( $\mathrm{T} 17)$.

Perhaps most importantly of all, as discussed earlier, contract work enabled people to be with their kin.

\section{The use of bush resources}

Nyungars in the Great Southern Region continued to hunt and gather bush resources. When people were in employment, they purchased basic grocery items such as tea, flour, sugar, potatoes, onions, baking powder and fat and, if they were working for farmers, they were sometimes supplied with mutton and, less commonly, dairy products. However, many Nyungars supplemented their diet with 'bush tucker' while they were employed, and when work was scarce this reliance became more pronounced - 'you lived off the bush mainly' ( $T$ 16). The administration was aware of this situation. When the scale of rations in Western Australia was lower for Aborigines than for others in the 1930s it appears that there was an assumption that Aborigines would supplement government rations with bush food. ${ }^{23}$ During the 1950s the Southern District Officer observed on a number of occasions that those who were out of work were living on damper and whatever meat could be caught or

23 WAPD 102, 1938, p. 2117; Rowley 1972, p. 49. 


\section{ABORIGINAL HISTORY $1993 \quad 17: 1$}

trapped. ${ }^{24}$ However, it must be noted here that economic necessity was not the only reason why people continued to pursue these activities. People relished the taste of bush tucker, ${ }^{25}$ and hunting and gathering were also enjoyed for their social and recreational value.

Rabbits were staple items for everyone, as were kangaroos for those who lived near uncleared bush country, and even people who were living on town reserves or at the Gnowangerup Mission went hunting at weekends (T 22). One man expressed his family's dependence on these important sources of food by saying 'I was reared up on kangaroo and rabbit' (T 9); and a woman remembered that her family ate 'stacks of rabbit - baked rabbit and rabbit stew and curried rabbit' (T 25). The introduction of myxomatosis in the 1950s, at a time when the demand for Aboriginal labour was starting to decline, was disastrous for Nyungars as the disease effectively removed a major item from their regular diet. Other sources of protein that were obtained from the bush included goanna, possum, birds, marron and gilgies (freshwater crustaceans), bardi grubs, emu and fish. Bush fruits and tubers which were obtained included tjork or korn, a kind of sweet bush potato which was roasted; kurnuk, kolberis and quandongs which were either eaten raw, stewed like plums or made into jam; and wild figs. Wild honey 'robbed' from trees was also highly prized.

Nyungars obtained not only 'bush tucker' from the environment but various other raw materials which were turned into useful items. Mattresses were made from 'blackboy' rushes: 'you'd lay it all one way and the next lot the other way and then the next lot that way, it contoured to your body ... spread the blanket on top of that' (T 25). Huts were also made from this material in the earlier part of the period. Rugs, known as waggas, were fashioned out of old jute bags stitched together as a ground sheet or backed with a blanket or the skins of kangaroo, rabbit or fox. They were used extensively to sit on and for bedding. In these ways, Nyungars continued to draw on indigenous resources and processes and thereby satisfied some of their material requirements outside the capitalist economy. The Nyungar economy can thus be described as entailing 'multiple enterprise', a term which Anderson ${ }^{26}$ uses in relation to Aboriginal economies which have components based both on wage labour and bush resources.

\section{Nyungar and capitalist values}

It is not easy as a non-Aboriginal researcher to determine retrospectively the extent to which Nyungars conformed to the European work ethic. Apart from the issues that arise when using oral history, which I will not attempt to address in this paper, ${ }^{27}$ there were obviously differences within the Nyungar community regarding the degree to which individuals accepted or rejected European values and behaviour. It was generally believed among farmers, for example, that training at missions made better workers: 'they copied the whites more and adopted their way of living more easily' (T 33). A Nyungar woman who became a nurse believed that her mother's insistence on careers for her daughters stemmed from her upbringing in a white family (T 26). In their studies of Aborigines in the Narrogin and Brookton areas respectively in the early 1960 's, Tonkinson and McMath ${ }^{28}$ concluded that, while the majority of Nyungars continued to hold economic values that were seen as constituting a 'barrier' to assimilation, there were several families in each town whose attitudes and behaviour were considered to be more European than Aboriginal. These

24 AR 1950, p. 11, AR 1953, p. 7; NW 94/1954.

25 cf. Toussaint 1987, p. 105.

26 Anderson 1980, p. 77.

A discussion of some of these issues is contained in an excellent article by Goodall 1987. I also found the work of the Popular Memory Group 1982 useful.

Tonkinson 1962; McMath 1962. 
families lived in town houses, held permanent jobs, and, in Narrogin, had very little contact with Aborigines living on the reserve.

It seemed, too, that different patterns of work behaviour may have prevailed in different areas. One man said that in the South West, where he had grown up, Nyungars were 'more sophisticated' and expected everyone to work five days a week, but when he moved further east, he felt less constrained to do this:

I'd pick up a few days here and there and ... I think I was getting two pound ten a day and three days, then I could live off that for the next couple of weeks ... if you wanted to work one day a week that was up to you (T 8).

In the area that he was speaking of, around Gnowangerup and Borden in the 1940s, there were still a number of full-time speakers of the Nyungar language, ${ }^{29}$ and he remembers ceremonies being performed at that time. It is likely, too, that, as well as geographical variations, Nyungars had different expectations of people at different stages of their life cycle, with young single men being given more leeway in terms of their economic behaviour than those with families.

The archival evidence and the oral testimonies of both Nyungars and their employers suggest that, generally, people did not submit meekly to the pressures exerted on them to perform in the manner expected by Europeans. Resistance to the imposition of the dominant culture's values regarding work can take many forms. In their study of the economic life of Aborigines on the far south coast of New South Wales, Castle and Hagan ${ }^{30}$ suggest that seasonal work - in this case bean picking - not only allowed Aborigines to retain some degree of independence and self-esteem, but also offered the opportunity for a little vengeance, since they could terminate their contract at any time. I have no evidence that this occurred in the Great Southern Region, but certainly those Europeans who treated Nyungars well appear to have had fewer problems with uncompleted contracts. One woman recounted with glee leaving her job on a chicken farm where she was expected to do all the housework as well as look after the chickens. She did not wait to obtain permission from the Department, and the first that her employers - 'the laziest mob of people I ever saw' - knew about it was a note on the kitchen table which said 'Gone home to Katanning, see ya' (T 28). During the early 1950s the Department received complaints about the growing 'truculence' of some workers, which was attributed to their growing awareness of their worth to farmers. The District Officer was apparently told by some farmers that they dare not take any action against such workers for fear of being burned out. ${ }^{31}$ It is impossible to tell whether this fear was based on reality or was a product of paranoia.

For Nyungars, the stealing of sheep to supplement an often meagre diet may also have contained an element of defiance. This seems to have been a not uncommon occurrence: 'knocking off the odd sheep here and there when you're starving, we didn't feel that was wrong, they had plenty of sheep' (T 7). It has also been suggested ${ }^{32}$ that illegal drinking and gambling by Aborigines - which it appears from the oral and archival material were happening in the Great Southern Region - constitute direct acts of defiance. Morris ${ }^{33}$ believes that these activities were not only a rejection of discriminatory legislation, but also

29 Even those Nyungars who were not competent at speaking the original language had a distinctive way of speaking. Douglas 1973, p. 49 has labelled this language, which is constructed from both English and the original Nyungar language, 'neo-Nyungar', and most Nyungars today still speak it.

30 Castle and Hagan 1978, p. 168.

31 AR 1950, p. 12.

32 Beckett 1964, p. 40; Morris 1988, p. 51.

33 Morris 1988, pp. 51-3. 
that their persistence was a political act in that they were collective group activities and the aim of assimilation was to instil a sense of individual rights and property in Aborigines. At the same time, he points out, drinking was also a means by which Aborigines accommodated to European domination and thus provides an example of the close connection between accommodation and resistance.

Moving away was one tactic that Nyungars used to avoid unwelcome attention from the Department's staff or the police. A documented instance of this refers to people moving out of a particular district to avoid prosecution for being 'idle and disorderly' at a time when there was no work available. ${ }^{34}$ On another occasion a family had 'gone bush' in order to avoid execution of a warrant for their removal. They had learnt of the warrant when the local paper published the proceedings of the Municipal Council's health and welfare committee at which the Department had informed the committee of their intended removal. ${ }^{35}$ The isolated position of many Nyungar families living out on farms, often helped to keep them away from the notice of the authorities.

Attempts by the Department to train the younger Nyungars frequently met with opposition. The Carrolup Native Settlement was reopened in 1940 ostensibly to provide education for children of mixed descent. It soon became evident, however, that it was to operate as a multipurpose institution to which Aborigines were removed because of lack of employment, poor living conditions, venereal disease and other illnesses, and 'intractable' behaviour, as well as for the purpose of formal education. ${ }^{36}$ Staff at the Settlement complained that most of the young men who were held under warrant were 'practically refusing to work ${ }^{137}$ and absconding and escapes from detention were common. The protests at the Settlement regarding the withholding of a portion of their wages for placement in a trust account and the issuing of store orders to the value of the remainder - protests that were ultimately successful - are further evidence that Nyungars were not passive in their response to the dictates of the Department. ${ }^{38}$ Even after the adoption of more subtle methods of inculcating European values, this resistance continued, as the following complaint made by Commissioner Middleton to his Minister in 1960 shows:

Just as many natives stubbornly refuse to accept any measures designed for

their personal welfare and advancement or their assimilation ... so it is that many of their teenagers do not want post primary education or training or being submitted to any restriction of their liberty in any shape or form ${ }^{39}$

The measures that were used by the administration to try to instil in Nyungars a sense of property and a desire to save appear to have met with mixed success. According to both Nyungars and farmers, a large proportion of people's earnings was spent on food so that often, when a contract was finished and the account for stores bought on their behalf had been settled, there was very little money left. Card playing and two-up were popular recreational activities in some areas, especially during the shearing season when earnings were generally higher than at other times of the year. Nyungars accumulated very few possessions, at least partly because of their need to be mobile, as the following extract explains:

\author{
NA $34 / 1949$. \\ NA $190 / 1949$. \\ NA $653 / 1940$. \\ ibid. \\ NA 964/1941; NA 3/1940. \\ NW AN number $1 / 7$ Acc. 1525 12-6/2.
}


You hadn't got much to carry, your blankets and tent if you'd got one, a couple of cups and a can, you might have a pan but you mightn't have a pot (T 21)

It was certainly important to Nyungars that they have money in their pockets, but they showed little desire to hoard it. Apart from one couple who said that they did so in order to have something to spend at the local agricultural show, none of the interviewees indicated that he or she had saved money. People were generally more interested in the immediate purchasing power of money; as one man explained 'none of us was banking any money, Nyungars get it to spend, gone today ...' (T 10).

Within the limits imposed by economic and political constraints Nyungars insisted on working in the way that best suited them. A common theme running through the narratives of non-Aboriginal people was the inability of employers to control fully the economic behaviour of Nyungar workers. Consequently farmers were sometimes frustrated by what they saw as the Nyungars' 'casual' attitude to work and yet felt powerless to change it.

\section{Relationships between Nyungars and farmers}

Employment provided one of the few points of contact between Nyungars and Europeans in the region and the patterns of interaction that developed within this context were thus important in determining Nyungar-European relations generally. The picture that emerges from the Aboriginal narratives and, to a lesser degree, from those of European farmers who employed them, is of fairly harmonious relationships between the two groups. Aborigines were almost unanimous in asserting that farmers were generally 'good blokes' who had treated them 'fairly'. Reluctance to criticise former employers to a white interviewer, as well as the somewhat unsatisfactory relations which exist today between the two groups in the region, may have contributed to a rosy representation of past race relations. Certainly, antagonisms and hostilities did exist on both sides, as comments made during interviews with both Nyungars and Europeans revealed. There were farmers who refused to employ Nyungars and, conversely, certain farmers for whom Nyungars would not work. At a less extreme level, each voiced complaints and dissatisfactions about the failings of the other group in the work situation. Nevertheless, it is clear from both sets of narratives that many of the encounters between farmers and Aboriginal workers were amicable and that their relationships were often characterised by genuine affection and respect.

Within their runs Nyungars had a number of employers or 'bosses' with whom they had a varying amount of contact. With those farmers who employed Nyungars only once a year to do their shearing, the relationship tended to be seen by both as a purely commercial transaction. Nevertheless, there was a measure of continuity involved since the same core of shearers usually returned each year to the sheds in their run. Shearers and shed hands would stay up to several weeks on each farm until they had 'cut out' the shed and were ready to move on to the next one. Between shearing seasons they had very little contact with these farmers apart from approaching them prior to the start of the shearing season for a 'sub', or cash advance, on their contract. For Aborigines, the sub system provided a means of tiding them over periods of unemployment and, although farmers complained about the system, it seems that many of them paid subs to Nyungar shearers while labour was scarce.

Most Nyungar families were associated with one or two particular farms within their runs to which they returned each year after they had completed shearing and whose owners they regarded as their 'main' bosses. They often remained on these farms for lengthy periods while the land was being developed - one man remembers as a child spending fifteen consecutive years on the same farm - although during slack periods they might 


\section{ABORIGINAL HISTORY 1993 17:1}

move temporarily to neighbouring farms. This association was expressed by Aborigines in terms of ownership; for example, 'certain Nyungars had their own farms they'd go to, they go there and work every year ... everybody knew where they were going' (T 19); or, as another man succinctly put it when talking about the farm where he spent much of his childhood: 'It was known as a [his family name] farm' (T 2). The characterisation of this sort of work arrangement by Nyungars as 'permanent' is indicative of the sense of security that was derived from these links to specific farmers, links that in earlier times were sometimes made explicit through the adoption of employers' names even where there was no biological connection. ${ }^{40}$ In the 1950 s and 1960 s, as work became more scarce, this pattern changed, and Nyungars rarely spent more than a few weeks on any one property, although even then the association often continued.

From the Nyungar perspective, the employer-employee relationship, particularly the one between themselves and their regular bosses, was a reciprocal one involving mutual obligations: 'you looked after them and they looked after you' (I 6). In return for their labour and loyalty, Nyungars expected that these bosses would either send for them when there was a job to be done or, when approached, would provide them with work or with a loan of cash or meat to tide them over the lean times. These loans were 'cut out' later when work was available (a practice that Nyungars referred to as 'like paying off a dead horse'), although it seems from the complaints of farmers that not all debts were discharged in this manner.

The connection which Nyungars felt to particular employers was recognised by these farmers. As one man, who had employed members of the same family as his father had done before him, said:

I think there was families associated with particular farms and I think that worked both ways, I think that a lot of Nyungars used to like to associate themselves with different farmers too (T 27).

Another white informant recalled that when her husband was sick, two boys whose family used to work for them came to visit:

They wanted to know how [he] was. They came just as friends, they weren't looking for anything or asking for anything ... maybe they feel that somehow they belong or we belong (T 31).

It was generally accepted amongst the farmers that Nyungars worked better for those whom they liked and respected and that they were more inclined to 'Iet down' employers whom they considered to be 'bad'. 41

Most employers understood that if they wanted access to a regular supply of labour, then they had to be prepared to meet their obligations in terms of providing loans and advances. Farmers complained frequently about the existence of bad debts, yet the continuation of the practice indicates that they realised that this was an integral part of the exchange between themselves and their regular workers. It would be wrong to ignore the fact that a genuine humanitarianism was also involved at times, as one farmer revealed when he talked about Nyungars who had shorn for him:

We knew darn well if they came here and asked for a sub they really needed it, so you couldn't refuse them, I think my dad appreciated that and I did, we didn't like lending people money but there is a reason there ( $T$ 27).

These links were not only recognised by the particular farmers who were party to them, but by everyone else in the European community. It was well known who were the main

40 Tilbrook 1983, p. 78; cf. Anderson 1983, p. 490.

41 NA 190/49. 


\section{NYUNGARS AND WORK IN SOUTHERN WESTERN AUSTRALIA}

employers of Aboriginal labour in each district; as one farmer said, 'it was accepted that we always have them here' (I 12).

While the relationships between Aborigines and their employers were individualistic, with perceptions varying on both sides as to who constituted a good boss or a good worker, it is possible to discern from the Aboriginal narratives that there were certain criteria used to evaluate an employer's behaviour. The first of these was the employer's perceived willingness to meet his obligations in terms of providing work, loans and meat as discussed earlier. It was also important that he demonstrate a degree of trust in his workers by leaving them to do the required work without supervision and by taking their word that they had completed a job. One old man referred to a farmer who used to employ a lot of Nyungars on his property as:

a good man - he used to tell you what to do and then he never seen you until you came back for your cheque. When you come back he never looked whether you'd done it or not, he'd pull his little drawer out and there was all cash, notes ... pay you up straight away ( $\mathrm{T} 12$ ).

Honesty in their dealings with their workers was another factor which was taken into account by Nyungars in judging employers. Before a contract was started a price would be agreed on by both parties. This was a verbal agreement and Nyungars say that some farmers tried to cheat them by dropping the price once the job had been completed. An old man recounted with amusement how he had discovered that a farmer had sewed an extra piece onto his measuring tape so that it would appear that the area of land that he was paying to have cleared was smaller than it actually was (T 33). The usual response, however, to this sort of tactic was to boycott the farmers who resorted to them. According to a man who had employed Nyungars for many years, it was impossible to exploit Aborigines:

If someone cheats them, they won't get them back on the property, they say

'no, he's not honest, he put it over me, don't you go and work for him'. That's your punishment for not giving him what you promised and also they'll never trust you again ( $\mathrm{T} 35)$.

Nyungars were also very sensitive to the attitude of their employers towards them and appreciated it when they were given the same treatment that they believed would be accorded a European worker. An old lady who had worked for a doctor and his wife in order to support herself and her children, said that 'they were wonderful, there was no sticking out on the woodheap and that, there was all one table' (T 21) The practice of feeding Aborigines outside was deeply resented, as one man's comments about a former employer indicate:

He'd feed you on the woodheap, that's where he fed me ... I was in the chaff cutting team, you know how dusty it is inside those big sheds. When we knocked off for dinner we had to eat out on the wood heap ... If I could get away with it, I'd burn him right out and him in the house with it too, he was a $\operatorname{dog} \ldots$ (T 12).

Another factor that contributed to the respect felt for a particular boss was the provision of meat and dairy products to employees, particularly when no charge was involved. If at least some of these requirements were met, then it appears that workers were willing to ignore or at least tolerate other less desirable traits in their employers. An incident recounted by one old man illustrates this point:

Another bloke down here ... when you worked for him ... he was a decent sort of a bloke in a lot of ways but us Nyungars couldn't get a beer in those times, you understand, we wasn't allowed. He'd come along and chuck a bottle of 


\section{ABORIGINAL HISTORY 1993 17:1}

beer to each one of us then he'd go back. He'd give us time to get rid of it, you see, then he'd write our cheques out. He'd come over to the fence then. 'Righto, you black fellas' - he wouldn't say black fellas he'd say something else, you know what I mean - 'come on you black' [here he knocks on the table four times], chuck all the cheques over the fence, now we got to sort our own cheques out ... That's how he used to pay us ... but he was a good fella, meet on the street he'd pull up and give a few bob, 'I've got work down here for you tomorrow'. We'd have to go down, see [laughs] (T 12).

The qualities that farmers valued in workers were reliability and honesty. There were complaints, voiced in the interviews and in the archival material, that Nyungars accepted 'subs' for jobs and then did not turn up or that they left before the work had been completed. Some farmers believed, too, that they had been deliberately tricked by particular Aborigines who had either accepted a price for a job and then, after they had started, demanded a higher one or who had only cleared roots and stones around the outside of the paddock and left the remainder untouched (T 23; T 31). Yet, despite this dissatisfaction with some workers, the dominant feeling was that those Nyungars who had been employed on a regular basis were good, reliable workers who could be trusted. Their skill in handling and shearing sheep was widely acknowledged: 'they didn't knock the sheep around' and 'they were clean shearers' were frequent comments. And they were generally seen to be 'slow but good' at clearing tasks. There was one other quality in employees that gained currency at certain times and that was sporting ability. A retired couple recalled that when more players were needed for the local football team an effort would be made to find jobs in the district for young Nyungar men, especially if they were members of families known to excel at the sport (T 31).

Although farmers were more inclined than Nyungars to regard the exchange between them as simply a commercial transaction, there were some who were paternalistic in their attitude to their regular employees. It seems that this type of relationship had its origins in an earlier time when the relationship was more obviously exploitative in terms of working conditions and return for labour. Certainly, it appears that the relationships that most closely resembled paternalism were those sustained by the older established landholding families and their Aboriginal workers, which had persisted across several generations on both sides. There tended to be a degree of possessiveness on the part of these European employers, as indicated by their references to 'our natives', and by their claims to a special understanding of Nyungars based on their long association with them. ${ }^{42}$ They were also protective of their workers. One Nyungar man partly attributes his father's success in preventing the removal of himself and his siblings to the Carrolup Native Settlement to the assistance of:

some farmers who backed him, backed him up ... I don't think they would allow them [i.e. Department of Native Affairs officers] on the property while we were there ... because we never saw them there but as soon as we got to Cranbrook, that's where we had them come there. They'd come there, they'd search the place (T 19).

There were certain farmers, too, who would allow other Nyungars apart from those who were working for them to camp on their property, thus providing a venue where people could 'meet up' away from the often hostile environment of the towns. That this was not a widely accepted practice is suggested by the following comments about the owner of a large property:

42 McGrath 1987 , p. 96, p. 100 makes a similar observation in her discussion of Aborigines and paternalism in the northern cattle industry. 


\section{NYUNGARS AND WORK IN SOUTHERN WESTERN AUSTRALIA}

He didn't seem to care if people was working for him or not, they could still go and stay there. Some of them would leave from there to go working, they'd be always welcome back on his property. They had to go past his house and his shed, he wouldn't say there's too many up there or something like that ( $T$ 19).

On another farm where up to a hundred Nyungars lived at any one time, anyone coming to pick up people for work or for football was required to let the farmer know before they took them off the property: as another farmer commented, 'they were sort of protective towards the Aborigines, they sort of took responsibility' (T 31). There was often a degree of benevolence in the attitude of these farmers towards their employees. This was revealed in such actions as the presentation of turkeys at Christmas time and the setting aside of a plot of land for burial purposes (T 34). In the latter case, workers were able to fulfil their desire to keep their dead on the property where many of them had been born and which they regarded as their home, and were also saved the expense of a town funeral. Sometimes the sense of responsibility extended beyond the grave, with farmers making provision for workers in their wills, instructing that particular Nyungars be given help when needed or allowed to camp on the property or, in one case where a man had worked for twenty-five years for the same family, to occupy the cottage which had been erected for him (T 10; I 10 ; I 11).

When considering the nature of the relationship between Nyungars and Europeans, it is impossible to ignore the existence of miscegenation which has had a profound effect on race relations in the region. Apart from one woman who commented that the resentment felt by the wives of European men who had fathered 'half-caste' children had affected attitudes to Nyungars, white informants were silent about this sensitive subject. Nyungars were more open. The subject of miscegenation was brought up by a number of the Aboriginal informants and it is clear from their comments that a considerable degree of bitterness still exists. One middle-aged man explained that it used to be a very common practice for 'cockies' in his area to 'knock around' with the young daughters of the Aboriginal people whom they employed, and although Nyungars did not like it, there was very little that they could do to prevent it. There was a law against non-Aborigines having sexual relations with Aborigines but he could not remember anybody being prosecuted; however, some men were taken to court and made to pay maintenance for their offspring (T 1). Nyungars are also bitter about the refusal of many of the farmers to acknowledge or 'own' their Aboriginal offspring and to provide for them. The grandfather of one informant was a wealthy landowner who employed a large number of Nyungars on his property and who fathered quite a few children. These children took his name but, when they were older and he brought his English bride to live there, he paid them to change their surname to avoid embarrassing her ( $T$ 25). There was always the fear, too, that the Department would be notified and the children removed from their mothers if it was obvious that there was no male partner. One strategy that was adopted in an attempt to prevent this was for these children to address their maternal grandparents as 'Mum' and 'Dad' (T 1).

In this discussion of the interaction between Nyungars and farmers in the region it has been shown that Nyungars were able to create a degree of security for themselves in an uncertain economic situation by developing particular and enduring relationships with some farmers. The strength of these ties is attested to by the fact that some of the long established relationships still endure today, even though the reason that led to their establishment - that is, the need for labour - no longer exists in the same way that it once did. That this is the case is largely due to the effort that some Nyungars put into maintaining the relationships. Where occasional work is still available, employers will 


\section{ABORIGINAL HISTORY 1993 17:1}

sometimes call for their old workers to do a few days' casual work (T 1; T 10; T 32). More commonly, though, the relationship is maintained on a purely social basis. Nyungars will make a point of visiting their former regular bosses even after they have moved away from the area and have just returned to see relatives or attend a funeral (T 1; T 33; I 8; T 31). Some farmers, too, continue to recognise the ties, allowing Nyungars to pick dead wool on their property and providing meat at a low cost as well as, less frequently, cash loans to former employees ( $\mathrm{T} 10 ; \mathrm{T} 28$; I 11). Even where physical contact is not maintained, both parties may still follow with interest major events in each other's lives, such as births, deaths and marriages.

\section{Nyungar assessment of their economic history}

The Nyungars who were interviewed are very proud of their work histories and of their former self-sufficiency. In the 1940s there was sufficient work to allow people a certain amount of choice about what they did to earn a living. Some preferred not to pick up stones, others avoided mallee stump picking - one said that as a young man he 'couldn't handle walking on to a thousand acres of mallee rootpicking and seeing one mass of mallee roots' ( $\mathrm{T}$ 7) - and almost everyone disliked picking dead wool. Young men in particular loved to drive machinery: 'us boys, we were happy as long as we were driving something that moved' (T 4). As farm work became scarcer, however, people had to be prepared to do anything: 'wherever I could get it, where it came I done it, couldn't do nothing else, I couldn't pick and choose from job to job' (T 12). This meant that they had to possess a wide range of skills. One man commented wryly that 'there were lots of skills in the unskilled labour market' (T 4), and another interviewee said proudly: 'I was an all round woman, I could do anything [laughs]' (T 21). They had to work hard in order to survive and they remember few occasions when they received assistance from the Department of Native Affairs (later Native Welfare). Rather, it is regarded primarily as the agency that was responsible for removing children from their families: 'all they wanted to do as far back as I can remember was get us and put us in Carrolup ... they would just take people with force' (T 19).

Nyungar people's recitations of their work histories, says Baines ${ }^{43}$ in a paper about Nyungar fringe dwellers, are their 'curriculum vitae' which serve to deny the negative stereotype of Aborigines as lazy and loath to work which is so often held by nonAborigines. She also maintains that Nyungars have countered the dispossession of their lands by labouring on the self-same land. ${ }^{44}$ Certainly, the country has meaning for them not only because of its associations with camping places, sources of water and particular kinds of food, and mythical happenings, but also in terms of the transformation wrought on it by Nyungars themselves - the paddocks cleared and fences erected. The following excerpts from the narratives illustrate this point:

My family cleared most of Knowangerup, Borden, Ongerup, all round there, it's just amazing how they worked (T 11).

I put a lot of the fences up near the mission, all still standing there, I cleared a lot of country there (T 32).

Nyungars are confident about the dominant position that they once occupied in the rural labour market:

All the shearing teams were Nyungars in those days, wadjalas [whites] had a job to get a job shearing, they were battling especially [in] the big sheds ...

43 Baines 1988, p. 231.

44 This comment is also made by McGrath 1987, p. 174 in reference to Aborigines on cattle stations. 


\section{NYUNGARS AND WORK IN SOUTHERN WESTERN AUSTRALIA}

Nyungars had the shearing game wrapped up right throughout the southern part of the State and in the wheatbelt as well (T 3).

... clearing new country, rolling down with tractors, ploughing, it was all Nyungar work. There was Nyungars in each town doing their work ... whether they were shearing, clearing, they were all doing their part in each little district, this went right through I think (T 10).

A widespread sentiment amongst older Nyungars is that they also played a pioneering role in the development of the land for agriculture, and that their contribution to the Great Southern Regional economy has largely been ignored. In Knowangerup several people pointed out that the local history book contains no reference to them apart from the first chapter which describes 'traditional' Aboriginal society at the time of European invasion. ${ }^{45}$ Farmers, too, they feel have kept silent:

I don't think the old farmers would have told the younger people who did clear their land. The younger blokes have got it in their minds these days that Nyungars are bludgers, loafers, they didn't care that the Nyungars were the ones that cleared their land and that they were underpaid to do it. That's the reason why these days they think nothing of Nyungars, they never respected Nyungars. If they saw what he had to do in those times, they would think a lot different now (T 19).

\section{Conclusion}

It has been. said that the ties that develop between people who are involved in collective and self-organised tasks serve to promote cultural unity and to increase the capacity of those people to resist domination. ${ }^{46} \mathrm{My}$ own findings support this claim: Contract work was the most prevalent form of work undertaken by Nyungars, who preferred it because they were able to choose with whom, how and where they worked and to hand down work skills from generation to generation. There emerges from both the Aboriginal and the European narratives a strong sense of Nyungars having created a degree of autonomy for themselves in their work lives, which challenges any depiction of them in official reports and earlier studies as passive victims. This autonomy, I argue, arose from the persistence of Nyungar economic values and work patterns within the constraints imposed by the State and the labour market and, in some situations, from direct opposition to the political and cultural domination of the State.

\section{LIST OF REFERENCES}

Anderson, C. 1980, Multiple enterprise: Contemporary Aboriginal subsistence strategy in southeast Cape York Peninsula, reprinted from Contemporary Cape York Peninsula: The Proceedings of a Symposium Held at the Kindler Lecture Theatre, Queensland Institute of Technology, 29th October, 1979, eds N.C. Stevens \& A. Bailey, Brisbane.

Anderson, C. 1983, 'Aborigines and tin mining in North Queensland: A case study in the anthropology of contact history', Mankind, vol. 13, no. 6, p. 473, p.498.

Baines, P.. 1988, 'A litany for land', in Being Black: Aboriginal Cultures in 'Settled' Australia, ed.'I. Keen, Canberra, pp.227-49.

45 It should be noted that this and other local history books in the region tend to ignore not only the contributions of Nyungars, but also of the working class and women. Instead, they provide a litany of the achievements of prominent individuals and families in each area.

46

Sider 1980. 
Beckett, J.R. 1964, 'Kinship, mobility and community among part-Aborigines in rural Australia, International Joumal of Comparative Sociology, vol. 6, no. 1, pp.7-23.

Birdsall, C. 1988, 'All one family', in Being Black: Aboriginal Cultures in 'Settled' Australia, ed. I. Keen, Canberra, pp.137-158.

Castle, R.G. \& Hagan, J.S. 1978, 'Dependence and independence', in Who Are Our Enemies? Racism and the Australian Working Class, eds A. Curthoys \& A. Markus, Sydney, pp.158-71.

Douglas, W.H. 1973, 'The language of southwestern Australia', Journal of the Royal Society of Western Australia, vol. 56, nos 1\&2, pp.48-50.

Goodall, H. 1987, 'Aboriginal history and the politics of information control', Oral History Association of Australia Journal, 9, 17-33.

Haebich, A. 1985, 'A bunch of cast-offs': Aborigines of the southwest of Western Australia, 1900$1936, \mathrm{PhD}$ thesis, School of Social Inquiry, Murdoch University.

1988, For Their Own Good: Aborigines and Government in the Southwest of Western Australia, 1900-1940, Nedlands, W.A.

McGrath, A. 1987, 'Born in the Cattle': Aborigines in Cattle Country, Sydney.

McMath, R.D. 1962, Problems of employment and assimilation among part-Aborigines of the Brookton area of Western Australia, unpublished honours dissertation, Dept of Anthropology, University of Western Australia.

Morris, B. 1983, 'From underemployment to unemployment: The changing role of Aborigines in a rural economy', Mankind, vol. 13, no. 6, pp. 499-516.

Morris, B. 1988, 'Dhan-gadi resistance to assimilation', in Being Black: Aboriginal Cultures in 'Settled' Australia, ed. I. Keen, Canberra, pp. 33-63.

Popular Memory Group 1982, 'Poplar memory: Theory, politics, method', in Making Histories: Studies in History-Writing and Politics, Centre for Contemporary Cultural Studies, London, pp. 205-52.

Sider, G.M. 1980, 'The ties that bind: Culture and agriculture, property and propriety in the Newfoundland fishing village', Social History, vol. 5, no. 1, pp. 1-39.

Thompson, E.P. 1967, 'Time, work-discipline, and industrial capitalism, Past and Present, vol. 38, pp. 56-97.

Tilbrook, L. 1983, Nyungar Tradition: Glimpses of Aborigines of South-Western Australia 18291914 , Nedlands, WA.

Tonkinson, R. 1962, Factors affecting movement and assimilation among part-Aborigines in the Narrogin district, unpublished honours dissertation, Dept of Anthropology, University of Western Australia.

Toussaint, S. 1987, Nyungars in the city: A study of policy, power and identity, MA thesis, University of Western Australia.

Ward, G. 1987, Wandering Girl, Broome.

Wolf, E. 1971, Peasant Wars of the Twentieth Century, London.

\section{WA Government Publications}

Annual Reports of the Department of Native Affairs and its successor, the Department of Native Welfare. Most of these were printed as Parliamentary Papers and the remainder can be found in the Aboriginal Affairs Planning Authority library. These reports are referred to by the letters AR followed by the relevant year.

Western Australia, Parliamentary Debates. These are referred to by the letters WAPD.

\section{Archival Material}

Files of the Department of Native Affairs and its successor, the Department of Native Welfare which are located in the State Archives. Unless stated otherwise, the accession number used to locate these files is 993 . These files are referred to by the letters NA or NW followed by the necessary identifying information. 